\title{
JALAN KAKI DAPAT MENURUNKAN TEKANAN DARAH PADA LANSIA
}

${ }^{1}$ Siti Rohimah, ${ }^{2}$ Novia Puspita Dewi

1,2 Prodi Keperawatan Universitas Galuh

Article Information

Received: Agustus 2021

Revised: November 2021

Available online : Januari 2022

Keywords

Hipertensi, jalan kaki, lansia

Correspondence

Phone: (+62)81323566058

E-mail : sitirohimahwibi@gmail.com

\section{ABSTRACT}

Hipertensi merupakan faktor penyebab utama kematian akibat stroke dan jantung coroner. Salah satu faktor yang mempengaruhi tekanan darah adalah aktivitas fisik. Penelitian ini bertujuan untuk mengetahui pengaruh aktivitas fisik jalan kaki terhadap tekanan darah pada lansia hipertensi di Desa Sindangkasih Kecamatan Sindangkasih Kabupaten Ciamis. Penelitian ini menggunakan metode quasi eksperimen pre-test post-test control group design. Pengambilan sampel dengan teknik purposive sampling lansia hipertensi derajat 1 dan diperoleh 30 responden yang terbagi menjadi 2 kelompok. Instrumen dalam penelitian ini menggunakan tensimeter. Analisis data menggunakan paired t-test. Hasil penelitian menunjukan adanya penurunan rata-rata tekanan darah sistolik pada responden kelompok intervensi sebesar $15 \mathrm{mmHg}$, sedangkan untuk penurunan ratarata tekanan darah diastolic sebesar $13 \mathrm{mmHg}$. Pada kelompok kontrol terjadi penurunan rata-rata tekanan darah sistolik sebesar $4,3 \mathrm{mmHg}$ dan penurunan ratarata tekanan darah diastolik sebesar $4 \mathrm{mmHg}$. Hasil analisa data menggunakan uji Independen Sample T-test didapatkan nilai signifikan $p$-value kelompok intervensi $=0,000$ dengan $\alpha=0,05$.Karena $p$-value $<0,05$ maka ada pengaruh aktivitas fisik jalan kaki terhadap tekanan darah pada lansia hipertensi di Desa Sindangkasih Kecamatan Sindangkasih Kabupaten Ciamis Tahun 2021. Kesimpulan penelitian ini adanya pengaruh aktivitas jalan kaki selama 30 menit terhadap tekanan darah sistolik dan diastolik pada lansia hipertensi. 


\section{PENDAHULUAN}

Populasi lansia di dunia diprediksi meningkat sangat cepat pada tahun 2020 dan berada di kisaran $11 \%$ dari 6,9 milyar populasi (WHO,2013). Jumlah populasi penduduk Indonesia usia 60 tahun lebih mencapai 24.754.500 jiwa (9,34\%) dari total populasi (WHO, 2013). Prevalensi penduduk lansia di Provinsi Jawa Barat berada di urutan ke-5 terbanyak penduduk lansia. Urutan ke-1 adalah Yogyakarta (12,48\%), urutan ke-2 Jawa Timur (9,36\%), urutan ke-3 Jawa Tengah $(9,26 \%)$, urutan ke-4 Bali $(8,77 \%)$ dan urutan ke5 yaitu Jawa Barat (7,09\%) dari total jumlah lansia di Indonesia (Badan Pusat Statistik,2019). Pada Tahun 2020 populasi penduduk lansia di Kabupaten Ciamis yang berumur 60-64 tahun mencapai 70.676 orang. Sedangkan pada usia 65-69 tahun mencapai 55.023 orang. Usia 70-74 mencapai 34.252 orang dan untuk usia 75 tahun lebih mencapai 38.757 orang (Badan Pusat Statistik, 2020).

Peningkatan jumlah lansia menjadikan suatu perhatian khusus bagi lansia yang mengalami suatu proses menua. Permasalahan-permasalahan tersebut diantaranya yaitu timbulnya perubahan fisik, kognitif, perasaan sosial dan seksual (Azizah, 2011). Lansia merupakan kelompok beresiko yang memiliki 3 karakteristik resiko kesehatan diantaranya ; resiko biologi termasuk resiko terkait usia, resiko sosial dan lingkungan serta resiko perilaku dan gaya hidup (Stanhope dan Lancaster, 2016). Proses penuaan mempengaruhi perubahan fisik dan mental yang mengakibatkan penurunan daya tahan tubuh lansia sehingga tubuh lansia menjadi rentan dan mengakibatkan timbulnya berbagai macam penyakit dan yang paling sering ditemukan yaitu hipertensi. Hipertensi merupakan urutan ke-1 (57,6\%) dari 6 masalah kesehatan lansia lainnya diantaranya , arthritis urutan ke-2 (51,09\%), stroke urutan ke-3 $(46,1 \%)$, masalah gigi dan mulut urutan ke-4 $(19,1 \%)$, urutan ke-5 Penyakit paru obstruktif menahun (8,6\%), dan Diabetes melitus berada pada urutan ke-6 (4,8\%) (Riskesdas, 2013 dalam Saelan, 2020).

Jumlah penderita hipertensi diperkirakan meningkat pada tahun 2025 dan akan ada 1,5 milyar orang yang terkena hipertensi serta setiap tahunnya akan ada 9,4 juta orang meninggal akibat hipertensi dan komplikasi (WHO, 2015). Prevalensi penduduk hipertensi di Indonesia saat ini mencapai 34,1\% dimana mengalami kenaikan dari tahun 2013 sebanyak 25,8 \% (Riskesdas,2018). Pada tahun 2015 Provinsi Jawa Barat ditemukan kasus hipertensi terbanyak mencapai (0,07\% terhadap jumlah penduduk $>18$ tahun) dari 22 Kabupaten/Kota Lainnya (Kemenkes Provinsi Jawa Barat, 2015). Kasus hipertensi di Ciamis tahun 2020 sebanyak 68.566 kasus (17,48\%) (Dinas Kesehatan Ciamis, 2020).

Hipertensi merupakan salah satu penyakit tidak menular yang menjadi perhatian dari semua kalangan masyarakat terutama lansia, sehingga membutuhkan penanganan jangka panjang yang menyeluruh dan terpadu. Hipertensi yang tidak terkontrol dapat menyebabkan peluang 7 kali lebih besar terkena stroke, 6 kali lebih besar terkena penyakit jantung koroner dan 3 kali lebih besar terkena serangan jantung. Pada kebanyakan kasus hipertensi terdeteksi ketika dilakukan pemeriksaan fisik karena alasan penyakit tertentu, sehingga sering disebut silent kill

Perubahan kondisi kesehatan dari hipertensi dapat mengenai berbagai organ target seperti jantung (penyakit jantung iskemik, hipertrofi ventrikel kiri, gagal jantung), otak (stroke), ginjal (gagal ginjal), mata (retinopati), juga arteri perifer (klaudikasio intermiten). Kerusakan organ tersebut bergantung pada tingginya tekanan darah pasien dan berapa lama tekanan darah tinggi tersebut terkontrol dan tidak diobati. Upaya untuk menurunkan angka resiko mortalitas penyakit seperti penyakit jantung iskemik dan stroke tersebut maka langkah 
yang diambil adalah dengan cara menurunkan tekanan darah sebesar 3,2 mmHg tekanan diastolik dan 5,7 mmHg tekanan sistolik pada penderita hipertensi tanpa pengobatan dengan cara melakukan aktivitas fisik jalan kaki (Silwanah, dkk 2020).

Penatalaksanaan hipertensi dapat dilakukan dengan 2 cara yaitu farmakologi dan non-farmakologi. Pengobatan farmakologi atau penggunaan obat antihipertensi seperti captopril, amlodiphine dan obat-obatan lainnya dapat menjadi pilihan, Penatalaksanaan hipertensi ke dua yaitu non-farmakologi dengan memodifikasi gaya hidup antara lain melalui upaya penurunan $B B$ yang dapat mengurangi tekanan darah 5-20 mmHg/penurunan $10 \mathrm{~kg}$ dengan mengurangi asupan kalori dan meningkatkan aktivitas fisik, adopsi pola makan DASH (Dietary Approaches to Stop Hypertension) dapat menurunkan tekanan darah 8-14 mmHg dengan banyak konsumsi buah-buahan sayuran. Kurangi asupan garam harian dapat menurunkan tekanan darah 2-8 $\mathrm{mmHg}$ kemudian yang terakhir yaitu dengan aktifitas fisik olahraga ringan seperti berjalan selama 30 menit dengan frekuensi 3-5 kali seminggu dapat menurunkan 3,2 - 5,7 mmHg (JNC8, 2016).

Peneliti menggunakan intervensi aktivitas fisik jalan kaki dikarenakan penatalaksanaan non-farmakologis ini tidak mengakibatkan efek samping bagi tubuh. Olahraga jalan kaki ini merupakan jenis olahraga yang sangat mudah karena setiap orang baik muda maupun orang tua dapat melakukannya. Murah karena tidak banyak peralatan yang diperlukan kecuali sepatu. Meriah karena dapat dilakukan dengan santai serta masal dapat dilakukan dalam satu regi kecil ataupun besar dan terakhir yaitu manfaatnya yang tidak diragukan lagi dapat menyehatkan dan menyegarkan jasmani.

\section{METODE}

Penelitian ini menggunakan metode quasi experiment atau rancangan eksperimen semu dengan bentuk rancangan nonequivalent control group yaitu penelitian yang dilakukan dengan membandingkan antara kelompok kontrol dan kelompok intervensi. Populasi pada penelitian ini adalah seluruh lansia yang menderita hipertensi yang ada di Posyandu Lansia Desa Sindangkasih Kecamatan Sindangkasih Kabupaten Ciamis sebanyak 88 lansia. Sampel dalam penelitian ini sebanyak 30 responden lansia hipertensi dengan kriteria inklusi lansia berusia 60 tahun atau lebih, 3) Tidak mengkonsumsi obat antihipertensi, sedangkan kriteria eklusinya adalah, perokok, alkoholik, penderita DM dan stress berat. data yang diambil secara langsung dengan memeriksa tekanan darah sebelum dan sesudah diberikan intervensi aktivitas fisik jalan kaki. Analisa bivariat pada penelitian menggunakan uji $t$ paired atau paired t-test. Uji $t$ paired atau paired t-test digunakan sebagai uji komparatif atau perbedaan, Pengujian juga dapat dilakukan melalui pengamatan nilai signifikan $t$ pada tingkat a yang digunakan (penelitian ini menggunakan tingkat a sebsar $5 \%$ ). Analisis didasarkan pada perbandingan antara nilai signifikan t dengan nilai signifikan 0,05.

\section{HASIL PENELITIAN DAN PEMBAHASAN}

\section{Karakteristik Responden Pada Kelompok Intervensi}

\begin{tabular}{ccc}
\hline & \multicolumn{2}{c}{ Kelompok Intervensi } \\
Karakteristik & Jumlah & $\%$ \\
& & \\
\hline Jenis Kelamin & & \\
Laki-Laki & 3 & 20 \\
Perempuan & 12 & 80 \\
Jumlah & 15 & 100 \\
Pekerjaan & &
\end{tabular}




\begin{tabular}{ccc} 
Petani & 3 & 20 \\
IRT & 12 & 80 \\
\hline Jumlah & 15 & 100 \\
\hline
\end{tabular}

Berdasarkan diatas menunjukan bahwa responden pada kelompok intervensi sebagian besar berjenis kelamin perempuan yaitu sebanyak 12 orang (80\%), pada jenis kelamin laki-laki berjumlah 3 orang (20\%). Pada karakteristik pekerjaan mayoritas yaitu ibu rumah tangga sebanyak 12 orang (80\%), dan petani sebanyak 3 orang (20\%).

Karakteristik Responden Pada Kelompok Kontrol

\begin{tabular}{ccc}
\hline \multirow{2}{*}{ Karakteristik } & \multicolumn{2}{c}{ Kelompok Kontrol } \\
& Jumlah & $\%$ \\
\hline $\begin{array}{c}\text { Jenis Kelamin } \\
\text { Laki-Laki }\end{array}$ & 1 & 6,7 \\
Perempuan & 14 & 93,3 \\
Jumlah & 15 & 100 \\
Pekerjaan & & \\
Petani & 4 & 26,7 \\
IRT & 7 & 46,6 \\
Pedagang & 4 & 26,7 \\
\hline Jumlah & 15 & 100 \\
\hline
\end{tabular}

Berdasarkan Tabel diatas menunjukan bahwa responden pada kelompok kontrol sebagian besar berjenis kelamin perempuan sebanyak 14 orang (93,3\%), pada jenis kelamin laki-laki sebanyak 1 orang (6,7\%). Pada karakteristik pekerjaan mayoritas adalah ibu rumah tangga sebanyak 7 orang (46,6\%), petani sebanyak 4 orang $(26,7 \%)$, dan pedagang sebanyak 4 orang $(26,7 \%)$.

Distribusi Frekuensi Tingkat Tekanan Darah Lansia Hipertensi Pada Kelompok Intervensi

\begin{tabular}{llccccc}
\hline & $\begin{array}{c}\text { Tekanan } \\
\text { Darah }\end{array}$ & N & Mean & SD & $\begin{array}{c}\text { SD } \\
\text { Error } \\
\text { Mean }\end{array}$ \\
\cline { 1 - 4 } Sistolik & Pre-test & 15 & 149,33 & & 7.528 & 1.944 \\
& Post-test & 15 & 134,00 & 10.556 & 2.726 \\
\multirow{2}{*}{ Diastolik } & Pre-test & 15 & 93.33 & 6.172 & 1.594 \\
& Post-test & 15 & 80.00 & 6.794 & 1.814
\end{tabular}

Berdasarkan tabel 4.3 menunjukan bahwa nilai rata-rata pre-test sistolik kelompok intervensi didapatkan hasil sebesar
149,33 sedangkan untuk nilai rata-rata posttest sistolik kelompok intervensi didapatkan hasil sebesar 134,00. Karena nilai rata-rata tekanan darah sistolik pre-test $149.33>$ posttest 134.00, maka artinya secara deskriptif ada perbedaan rata-rata hasil tekanan darah sistolik antara pre-test dengan post-test. Untuk nilai standar deviasi pre-test sistolik kelompok intervensi didapatkan hasil sebesar 7.528 sedangkan untuk nilai standar deviasi post-test sistolik kelompok intervensi sebanyak 10.556 . Karena nilai standar deviasi tekanan darah sistolik pre-test 7.528 dan posttest 10.556 maka nilai standar deviasi < nilai rata-rata mean artinya data sampel semakin homogeny (hampir sama). Terakhir adalah nilai standar error mean pre-test sistolik pada kelompok intervensi didapatkan hasil sebesar 1.944 dan untuk nilai standar error mean posttest sistolik kelompok intervensi didapatkan hasil sebesar 2.726. Karena nilai standar error mean tekanan darah sistolik pre-test 1.944 dan post test 2.726 maka nilai standar error mean $<$ nilai rata-rata mean yang artinya mengindikasikan bahwa sampel bagus / mewakili populasi yang sedang diteliti .

Selanjutnya untuk nilai rata-rata pretest diastolik kelompok intervensi didapatkan hasil sebesar 93.33 sedangkan untuk nilai ratarata post-test diastolik kelompok intervensi didapatkan hasil sebesar 80.00. Karena nilai rata-rata tekanan darah diastolik pre-test 93,33 > post-test 80.00 maka artinya secara deskriptif ada perbedaan rata-rata hasil tekanan darah diastolik antara pre-test dengan post-test. Untuk nilai standar deviasi pre-test diastolik kelompok intervensi didapatkan hasil sebesar 6.172 sedangkan untuk nilai standar deviasi post-test diastolik kelompok intervensi sebesar 6.794. karena nilai standar deviasi pre-test 6.172 dan post test 6.794 maka nilai standar deviasi < dari nilai rata-rata yang artinya secara deskriptif data sampel semakin homogen (hampir sama). Terakhir adalah nilai standar error mean pre- 
test diastolik pada kelompok intervensi didapatkan hasil sebesar 1.594 dan untuk nilai standar error mean post-test diastolik kelompok intervensi sebesar 1.814. Karena nilai standar error mean tekanan darah diastolik pre-test 1.594 dan post test 1.814

Distribusi Frekuensi Tingkat Tekanan Darah Lansia Hipertensi Pada Kelompok Kontrol

\begin{tabular}{llllll}
\hline & $\begin{array}{c}\text { Tekanan } \\
\text { Darah }\end{array}$ & N & Mean & SD & SD Error Mean \\
\hline \multirow{2}{*}{ Sistolik } & Pre-test & 15 & 150.67 & 8.423 & 2.175 \\
& Post-test & 15 & 145.36 & 6.640 & 1.775 \\
\multirow{2}{*}{ Diastolik } & Pre-test & 15 & 94.00 & 7.368 & 1.902 \\
& Post-test & 15 & 90.00 & 8.771 & 2.344 \\
\hline
\end{tabular}

Berdasarkan diatas menunjukan bahwa nilai rata-rata pre-test sistolik kelompok kontrol didapatkan hasil sebesar 150.67 sedangkan untuk nilai rata-rata posttest sistolik kelompok kontrol didapatkan hasil sebesar 145.36. Karena nilai rata-rata tekanan darah sistolik pre-test $150.67>$ posttest 145.36 , maka artinya secara deskriptif ada perbedaan rata-rata hasil tekanan darah sistolik antara pre-test dengan post-test. Untuk nilai standar deviasi pre-test sistolik kelompok kontrol didapatkan hasil sebesar 8.423 sedangkan untuk nilai standar deviasi post-test sistolik kelompok kontrol sebanyak 6.640. Karena nilai standar deviasi tekanan darah sistolik pre-test 8.423 dan post-test 6.640 maka artinya nilai standar deviasi < dari nilai rata-rata yang artinya secara deskriptif data sampel semakin homogen (hampir sama). Terakhir adalah nilai standar error mean pre-test sistolik pada kelompok kontrol didapatkan hasil sebesar 2.175 dan untuk nilai standar error mean post-test sistolik kelompok kontrol didapatkan hasil sebesar 1.775. Karena nilai standar error mean tekanan darah sistolik pre-test 2.175 dan post test 1.775 maka artinya nilai standar error mean < dari nilai rata-rata yang mengindikasikan bahwa sampel bagus / mewakili populasi yang sedang diteliti maka nilai standar error mean < dari nilai ratarata yang artinya secara deskriptif mengindikasikan bahwa sampel bagus / mewakili populasi yang sedang diteliti. 


\begin{tabular}{|c|c|c|c|c|c|}
\hline engaruh Aktivitas Fisik Jala & si Ter & \multirow[b]{2}{*}{ SD } & ianan [ & h Pada & \multirow[b]{2}{*}{ P-value } \\
\hline Variabel & Mean & & \multicolumn{2}{|r|}{$\mathrm{Cl} 95 \%$} & \\
\hline Pre-test Sistolik Intervensi & $149 \cdot 33$ & 7.528 & & & \\
\hline $\begin{array}{l}\text { Post-test Sistolik } \\
\text { Intervensi }\end{array}$ & 134.00 & 10.556 & 11.493 & 19.174 & 0,000 \\
\hline $\begin{array}{l}\text { Pre-test Diastolik } \\
\text { Intervensi }\end{array}$ & $93 \cdot 33$ & 6.172 & 7.538 & 19.129 & 0,000 \\
\hline $\begin{array}{l}\text { Post-test Diastolik } \\
\text { Intervensi }\end{array}$ & 80.00 & 6.547 & & & \\
\hline Pre-test Sistolik Kontrol & 150.67 & 8.423 & & & \\
\hline $\begin{array}{l}\text { Post-test Sistolik } \\
\text { Intervensi }\end{array}$ & 146.33 & 7.432 & 883 & 7.783 & 0,017 \\
\hline Pre-test Diastolik Kontrol & 94.00 & 7.368 & & & \\
\hline $\begin{array}{l}\text { Post-test Diastolik } \\
\text { Intervensi }\end{array}$ & 90.00 & 8.452 & -080 & 8.080 & 0,054 \\
\hline
\end{tabular}

Berdasarkan tabel di atas, menunjukan bahwa nilai rata-rata tekanan darah pre-test sistolik kelompok intervensi adalah sebesar 149.33 dan post-test sistolik kelompok intervensi aktivitas fisik jalan kaki adalah sebesar 134.00. Sedangkan untuk hasil ratarata tekanan darah pre-test diastolik kelompok intervensi adalah sebesar 93.00 dan post-test diastolik kelompok intervensi adalah sebesar 80.00. Penurunan nilai rata-rata tekanan darah sistolik pada responden sebelum dan sesudah diberikan intervensi adalah sebesar $15 \mathrm{mmHg}$, sedangkan untuk penurunan nilai rata-rata tekanan darah diastolik pada responden sebelum dan sesudah diberikan intervensi adalah sebesar $13 \mathrm{mmHg}$ sehingga dapat disimpulkan terjadi penurunan tekanan darah sistolik dan diastolik sebelum dan sesudah diberikan intervensi.

Untuk nilai rata-rata tekanan darah pretest sistolik kelompok kontrol adalah sebesar
150.67 dan post-test sistolik kelompok kontrol tanpa diberikan aktivitas fisik jalan kaki adalah sebesar 146.33. Sedangkan untuk hasil ratarata tekanan darah pre-test diastolik kelompok kontrol adalah sebesar 94.00 dan post-test diastolik kelompok kontrol adalah sebesar 90.00. Dengan menggunakan SPSS 16.00 for Windows diperoleh hasil standar deviasi pre-test sistolik kelompok intervensi sebesar 7.528 post-test sistolik kelompok intervensi sebesar 10.556 , pre test diastolik kelompok intervensi sebesar 6.172 dan post test diastolik kelompok intervensi sebesar 6.547. Sedangkan untuk hasil standar deviasi pre-test sistolik kelompok kontrol sebesar 8.423 post-test sistolik kelompok kontrol sebesar 7.432, pre test diastolik kelompok kontrol sebesar 7.368 dan post test diastolik kelompok kontrol sebesar 8.452. Nilai lower pre-test sistolik dan post-test sistolik kelompok intervensi adalah sebesar 11.493, dan nilai lower pre-test diastolik dan post-test 
diastolik kelompok intervensi adalah sebesar 7.538. Sedangkan untuk nilai lower pre-test sistolik dan post-test sistolik kelompok kontrol adalah sebesar ,883, dan nilai lower pre-test diastolik dan post-test diastolic kelompok kontrol adalah sebesar -080. Untuk nilai upper pre-test sistolik dan post-test sistolik kelompok intervensi adalah sebesar 19.174, dan nilai upper pre-test diastolik dan post-test diastolik kelompok intervensi adalah sebesar 19.129. Sedangkan untuk nilai upper pre-test sistolik dan post-test sistolik kelompok kontrol adalah sebesar 7.789, dan nilai upper pre-test diastolik dan post-test diastolik kelompok kontrol adalah sebesar 8.080 .

Setelah dianalisa dengan menggunakan uji T-test Sample Paired, untuk melihat pengaruh dari aktivitas fisik jalan kaki pada responden kelompok intervensi menunjukan bahwa ada nilai yang bermakna dari pengaruh aktivitas fisik jalan kaki terhadap tekanan darah dengan tingkat signifikasi p: 0,000. Karena nilai $p$ sistolik dan diastolic $<0,05$ maka dapat disimpulkan bahwa terdapat adanya pengaruh aktivitas jalan kaki terhadap tekanan darah pada lansia hipertensi di Desa Sindangkasih Kecamatan Sindangkasih Kabupaten Ciamis Tahun 2021.

Untuk responden kelompok kontrol menunjukan hasil tingkat signifikasi p: 0,017 untuk sistolik dan $p: 0,054$ untuk diastolik. Karena nilai sistolik $p<0,05$ maka dapat disimpulkan bahwa terdapat adanya pengaruh aktivitas jalan kaki terhadap tekanan darah pada lansia hipertensi kelompok kontrol di Desa Sindangkasih Kecamatan Sindangkasih Kabupaten Ciamis Tahun 2021. Untuk nilai diastolic kelompok kontrol didapatkan nilai $p>0,05$ maka dapat disimpulkan bahwa tidak terdapat adanya pengaruh aktivitas jalan kaki terhadap tekanan darah pada lansia hipertensi kelompok kontrol di Desa Sindangkasih Kecamatan Sindangkasih Kabupaten Ciamis
Tahun 2021. Walaupun Keduanya menunjukan nilai p-value $<0,05$ tetapi dapat terlihat bahwa ada nilai bermakna dari hasil penurunan ratarata (mean) pada kelompok yang dilakukan aktivitas fisik jalan kaki cenderung lebih besar dibandingkan dengan kelompok kontrol tanpa diberikan aktivitas fifik jalan kaki.

Berdasarkan hasil penelitian menunjukan bahwa nilai rata-rata tekanan darah pre-test sistolik kelompok intervensi adalah sebesar 149.33 dan post-test sistolik kelompok intervensi aktivitas fisik jalan kaki adalah sebesar 134.00. Sedangkan untuk hasil rata-rata tekanan darah pre-test diastolik kelompok intervensi adalah sebesar 93.00 dan post-test diastolik kelompok intervensi adalah sebesar 80.00. Penurunan nilai rata-rata tekanan darah sistolik pada responden sebelum dan sesudah diberikan intervensi adalah sebesar $15 \mathrm{mmHg}$, sedangkan untuk penurunan nilai rata-rata tekanan darah diastolik pada responden sebelum dan sesudah diberikan intervensi adalah sebesar $13 \mathrm{mmHg}$ sehingga dapat disimpulkan terjadi penurunan tekanan darah sistolik dan diastolik sebelum dan sesudah diberikan intervensi.

Untuk nilai rata-rata tekanan darah pretest sistolik kelompok kontrol adalah sebesar 150.67 dan post-test sistolik kelompok kontrol tanpa diberikan aktivitas fisik jalan kaki adalah sebesar 146.33. Sedangkan untuk hasil ratarata tekanan darah pre-test diastolik kelompok kontrol adalah sebesar 94.00 dan post-test diastolik kelompok kontrol adalah sebesar 90.00.

Hasil uji statistik t-test kelompok intervensi menunjukan nilai $p$-value sebesar $0,000(p<0,05)$ dengan demikian nilai $p$-value lebih kecil dari 0,05 sehingga $\mathrm{Ha}$ diterima disimpulkan bahwa terdapat pengaruh yang signifikan antara sebelum dan sesudah diberikan intervensi aktivitas fisik jalan kaki terhadap tekanan darah pada lansia hipertensi 
di Desa Sindangkasih Kecamatan Sindangkasih Kabupaten Ciamis Tahun 2021.

Hasil uji statistik t-test kelompok kontrol menunjukan nilai $p$-value sebesar 0,017 untuk sistolik $(p<0,05)$ dan 0,054 untuk diastolik $(p>0,05)$ dengan demikian nilai $p$ value lebih besar dari 0,05 sehingga Ha ditolak disimpulkan bahwa tidak terdapat pengaruh aktivitas fisik jalan kaki terhadap tekanan darah pada lansia hipertensi kelompok kontrol di Desa Sindangkasih Kecamatan Sindangkasih Kabupaten Ciamis Tahun 2021.

Dengan melakukan aktivitas fisik jalan kaki dapat meningkatkan aktivitas simpatis, menurunkan aktivitas parasimpatis dan ,meningkatkan aktivitas otot rangka. Akibat dari peningkatan aktivitas simpatis dan penurunan aktivitas parasimpatis tersebut dan meningkatkan denyut jantung, curah jantung, dan peningkatan tekanan darah. Namun setelah dilakukan olahraga secara teratur maka akan terjadi penurunan vasopressin, peningkatan efisiensi kerja jantung, dan penurunan aktivitas simpatis. Akibat dari terjadinya penurunan vasopressin dan peningkatan efisiensi kerja jantung tersebut menyebabkan curah jantung menurun diikuti penurunan tekanan darah sistolik. Penurunan aktivitas simpatis menyebabkan terjadinya vasodilatasi pembuluh darah, dan resistensi perifer total diikuti penurunan tekanan darah diastolik.

Pada responden kelompok intervensi sebagian besar berjenis kelamin perempuan yaitu sebanyak 12 orang (80\%), pada jenis kelamin laki-laki berjumlah 3 orang (20\%). Untuk responden kelompok kontrol sebagian besar berjenis kelamin perempuan yaitu sebanyak 14 orang (93,3\%), pada jenis kelamin laki-laki sebanyak 1 orang $(6,7 \%)$.

Hasil penelitian ini didukung dengan beberapa penelitian seperti ditemukan oleh Azhari (2017) tentang faktor-faktor yang berhubungan dengan kejadian hipertensi di puskesmas makrayu kebarat II Palembang menunjukan bahwa adanya hubungan antara jenis kelamin dengan kejadian hipertensi dengan nilai Odds ratio $(O R)=2,708$, ini menunjukan bahwa partisipan yang berjenis kelamin perempuan memiliki peluang lebih besar sebanyak 2,7 kali untuk terkena penyakit hipertensi dibandingkan dengan partisipan berjenis kelamin laki-laki (Azhari, 2017).

Wanita yang mengalami menopause merupakan salah satu faktor penyebab wanita memiliki kecenderungan angka kejadian hipertensi lebih tinggi daripada laki-laki. Pernyataan ini didukung oleh penelitian yang dilakukan Wahyuni dan Eksanoto (2013) bahwa perempuan akan mengalami peningkatan resiko hipertensi setelah menopause yaitu diatas 45 tahun. perempuan yang mengalami menopause memiliki kadar estrogen yang rendah. Sedangkan estrogen ini berfungsi menjaga kesehatan pembuluh darah (Wahyuni dan Eksanto, 2017).

Pada karakteristik kelompok intervensi pekerjaan mayoritas yaitu ibu rumah tangga sebanyak 12 orang (80\%), dan petani sebanyak 3 orang (20\%). Sedangkan pada kelompok kontrol karakteristik pekerjaan mayoritas adalah ibu rumah tangga sebanyak 7 orang (46,6\%), petani sebanyak 4 orang $(26,7 \%)$, dan pedagang sebanyak 4 orang $(26,7 \%)$. Karakteristik pekerjaan berpengaruh terhadap aktivitas fisik seseorang. Orang yang tidak bekerja aktifitasnya tidak banyak sehingga dapat meningkatkan kejadian hipertensi. Hal ini didukung oleh penelitian Lewa dkk, bahwa lansia yang tidak melakukan aktivitas fisik berhubungan dengan kejadian HST (Hipertensi Sistolik Terisolasi) yaitu dengan angka kejadian sebesar 2,366 kali beresiko terkena hipertensi. Hipertensi sistolik terisolasi yaitu hipertensi yang terjadi ketika tekanan darah sistolik mencapai 140 $\mathrm{mmHg}$ atau lebih. Jadi tekanan darah diastolik masih dalam kisaran normal sedangkan tekanan sistolik cenderung tinggi (Lewa dalam Syarifah, 2018). 
Dari permasalahan yang ada, peneliti memfokuskan pada manajemen penurunan tekanan darah dengan tindakan nonfarmakologis yaitu dengan melakukan aktivitas fisik jalan kaki.

Menurut penelitian yang dilakukan oleh Hatta dkk di Pusat Pelayanan Sosial Lanjut Usia Mappakasunggu Pare-Pare tentang "Pengaruh Aktivitas Fisik Jalan Pagi Terhadap Penurunan Tekanan Darah pada Penderita Hipertensi di Pusat Pelayanan Sosial Lanjut Usia Mappakasunggu Pare-Pare" dalam penelitian ini 20 responden diberikan aktivitas fisik jalan kaki selama 30 menit dengan frekuensi 4 kali dalam seminggu dan didapatkan hasil terjadi penurunan tekanan darah sistolik sebesar $20 \mathrm{mmHg}$ dan pada tekanan diastolic sebesar $10 \mathrm{mmHg}$ (Hatta, 2020).

Penulis menggunakan intervensi aktivitas fisik jalan kaki dikarenakan olahraga jalan kaki ini merupakan jenis olahraga yang sangat mudah karena setiap orang baik muda maupun orang tua dapat melakukannya. Murah karena tidak banyak peralatan yang diperlukan kecuali sepatu. Meriah karena dapat dilakukan dengan santai serta masal dapat dilakukan dalam satu regi kecil ataupun besar dan terakhir yaitu manfaatnya yang tidak diragukan lagi dapat menyehatkan dan menyegarkan jasmani. Penurunan tekanan darah pada pasien hipertensi setelah dilakukan aktivitas fisik jalan kaki disebabkan karena terjadinya beberapa mekanisme dalam tubuh yaitu penurunan aktivitas sistem saraf simpatis, penurunan resistensi total perifer vascular, penurunan curah jantung, meningkatnya sensitivitas baro reflex dan menurunnya volume plasma. Latihan berjalan kaki dapat menurunkan tekanan darah harian baik pada saat istirahat maupun saat aktivitas (Tiwari dalam Siti, 2017)

Hasil penelitian yang dilakukan oleh Khomarun menunjukan bahwa tekanan darah pada lansia pre dan post pemberian intervensi aktivitas berjalan mengalami perbedaan yang bermakna, sehingga ada pengaruh aktivitas fisik jalan pagi terhadap penurunan tekanan darah pada lansia dengan hipertensi derajat 1 di Posyandu Lansia Desa Makamhaji. Begitu pula dengan hasil penelitian yang dilakukan oleh Siti Munawarah di Pisangan Barat Ciputat tentang “Pengaruh Jalan Santai Terhdap Tekanan Darah Pada Penderita aHipertensi Warga RW 005 Pisangan Barat Ciputat" dalam penelitian ini 15 responden diberikan aktivitas jalan kaki dengan frekuensi 3 kali dalam seminggu dengan hasil adanya penurunan tekanan sistolik sebesar 9,11 $\mathrm{mmHg}$ dan tekanan darah diastolik sebesar $5,3 \mathrm{mmHg}$ (Siti Munawarah, 2020).

Surbakti (2014) menyatakan bahwa berjalan kaki berpengaruh terhadap kebugaran yaitu berjalan kaki dapat menurunkan lemak dan memperkuat otot. Berjalan kaki 2/3 kali dalam 1 minggu paling sedikit dalam waktu 20 menit akan meningkatkan pembuluh jantung. Meningkatnya ketahanan maka jantung dan paru-paru akan meningkatkan kemampuan tidak hanya berlatih lama dan lebih kuat tetapi juga dapat meningkatkan energi dalam melakukan aktivitas sehari-hari (Surbakti dalam Aliftitah, 2020).

Latihan fisik yang disarankan bagi penderita hipertensi adalah dengan intensitas sedang (dengan estimasi 50\% VO2 max), yang secara signifikan dapat menurunkan tekanan darah 4-9 mmHg melalui latihan fisik 30 menit/minggu, sampai dengan penurunan tekanan darah terbesar jika latihan fisik dilakukan 60-90 menit/minggunya.

Pengaruh aktivitas fisik jalan kaki terhadap tekanan darah pada lansia hipertensi dapat diperoleh dari perbandingan nilai $p$-value $=0,000$ atau probabilitas dibawah 0,05 (0,000 < 0,05), maka Ha diterima yang artinya terdapat pengaruh aktivitas fisik jalan kaki terhadap tekanan darah pada lansia 
hipertensi di Desa Sindangkasih Kecamatan Sindangkasih Kabupaten Ciamis.

Hasil penelitian diketahui kelompok intervensi dengan perlakuan aktivitas fisik jalan kaki lebih tinggi hasilnya dalam menurunkan tekanan darah dengan rata-rata tekanan darah pre-test sistolik kelompok intervensi adalah sebesar 149.33 dan post-test sistolik kelompok intervensi aktivitas fisik jalan kaki adalah sebesar 134.00. Sedangkan untuk hasil rata-rata tekanan darah pre-test diastolik kelompok intervensi adalah sebesar 93.00 dan post-test diastolik kelompok intervensi adalah sebesar 80.00.

Setelah dianalisa dengan menggunakan uji $T$ Test Sample Paired, untuk melihat pengaruh dari aktivitas fisik jalan kaki pada responden kelompok ntervensi menunjukan bahwa ada nilai bermakna dari pengaruh aktivitas fisik jalan kaki terhadap penurunan tekanan darah dengan tingkat signifikasi $p$ : 0,000. Karena nilai $p<0,05$ maka dapat disimpulkan bahwa terdapat pengaruh aktivitas fisik jalan kaki terhadap tekanan darah. Sedangkan untuk kelompok kontrol didapatkan hasil dengan tingkat signifikasi $p$ : 0,017 untuk sistolik dan p: 0,054 untuk diastolik. Karena nilai $p$ diastolic > 0,05 maka dapat disimpulkan bahwa tidak terdapat pengaruh aktivitas fisik jalan kaki terhadap tekanan darah pada lansia kelompok kontrol.

\section{SIMPULAN}

Walaupun Kedua kelompok menunjukan nilai $p$-value $<0,05$ tetapi dapat terlihat bahwa ada nilai bermakna dari hasil penurunan rata-rata (mean) pada kelompok yang dilakukan aktivitas fisik jalan kaki cenderung lebih besar dibandingkan dengan kelompok kontrol tanpa diberikan aktivitas fifik jalan kaki

\section{DAFTAR PUSTAKA}

Dewasa, P. P. H. JNC 8: Evidence-based Guideline.
Dewi, Rhosma, S. 2012. Keperawatan Gerontik. Cv Budi Utama.

Hastuti A,P. 2019. Hipertensi. Lakeisha (Anggota IKAPI).

Imelda, I., Sjaaf, F., \& PAF, T. P. (2020). FaktorFaktor yang Berhubungan dengan Kejadian Hipertensi pada Lansia di Puskesmas Air Dingin Lubuk Minturun. Health and Medical Journal, 2(2), 68-77.

Karim, N. A., Onibala, F., \& Kallo, V. (2018). Hubungan aktivitas fisik dengan derajat hipertensi pada pasien rawat jalan di wilayah kerja Puskesmas Tagulandang Kabupaten Sitaro. Jurnal Keperawatan, 6(1).

Khomarun, K., Nugroho, M. A., \& Wahyuni, E. S. (2014). Pengaruh aktivitas fisik jalan pagi terhadap penurunan tekanan darah pada lansia dengan hipertensi stadium I di Posyandu Lansia Desa Makamhaji. Interest: Jurnal Ilmu Kesehatan, 3(2).

Manuntung, A. 2018. Terapi Perilaku Kognitif Pada Pasien Hipertensi. Wineka Media.

Pramono, L. A., \& Fanumbi, C. (2012). Permasalahan Lanjut Usia di Daerah Perdesaan Terpencil. Kesmas: Jurnal Kesehatan Masyarakat Nasional (National Public Health Journal), 6(5), 201-211.

Pramono, L. A., \& Fanumbi, C. (2012). Permasalahan Lanjut Usia di Daerah Perdesaan Terpencil. Kesmas: Jurnal Kesehatan Masyarakat Nasional (National Public Health Journal), 6(5), 201-211.

Saelan, S., Adi, G. S., Kurniawan, S. T., \& Ardian, K. (2020). Efek Senam Lanjut Usia Terhadap Peningkatan Aktifitas Fisik Lanjut Usia Di Dusun Bonorejo Kelurahan Plesungan. Wiraraja Medika: Jurnal Kesehatan, 10(1), 17-22.

Junaidi, S. (2011). Pembinaan fisik lansia melalui aktivitas olahraga jalan kaki. Media IImu Keolahragaan Indonesia, 1(1). 
Karim, N. A., Onibala, F., \& Kallo, V. (2018). Hubungan aktivitas fisik dengan derajat hipertensi pada pasien rawat jalan di wilayah kerja Puskesmas Tagulandang Kabupaten Sitaro. Jurnal Keperawatan, 6(1).

Khomarun, K., Nugroho, M. A., \& Wahyuni, E. S. (2014). Pengaruh aktivitas fisik jalan pagi terhadap penurunan tekanan darah pada lansia dengan hipertensi stadium I di Posyandu Lansia Desa Makamhaji. Interest: Jurnal Ilmu Kesehatan, 3(2).

Manuntung, A. 2018. Terapi Perilaku Kognitif Pada Pasien Hipertensi. Wineka Media.

Muhith Abdul, Siyoto Sundo. Pendidikan Keperawatan Gerontik. CV ANDI OFFSET.

Munawarah, S. (2017). Pengaruh Jalan Santai terhadap tekanan darah pada penderita hipertensi warga RW 005 pisangan barat Ciputat (Bachelor's thesis, UIN Syarif Hidayatullah Jakarta: Fakultas Kedokteran dan Ilmu Kesehatan, 2017).

Nadirawati, N., Ismafiaty, I., \& Yulia, D. (2018). THE EFFECT OF LAUGHING THERAPY ON BLOOD PRESSURE IN ELDERLY WITH HYPERTENSION DEGREE II AT CIPAGERAN COMMUNITY HEALTH CENTRE WORKING AREA IN CIMAHI. Prosiding PIN-LITAMAS 1, 1(1), 9-20.
Raynaldo, A. H. (2019). Latihan Fisik pada Pasien Hipertensi.

Rizka, M., \& Agus, A. (2018). Pengaruh Latihan Jalan Kaki Terhadap Kebugaran Jasmani Lansia di Puskesmas Sungai Aur Kabupaten Pasaman Barat. JURNAL STAMINA, 1(1), 206-218.

Sarastuti, A. W., \& Widyantoro, B. (2018). Latihan Fisik bagi Penderita Hipertensi. Cermin Dunia Kedokteran, 45(12), 930933.

Sari, A., \& Salmiyati, S. (2018). Pengaruh Aktivitas Fisik Jalan Pagi Terhadap Tingkat Hipertensi Lansia di Dusun Biru Trihanggo Gamping Sleman

Sarbini Dwi, dkk. 2019. Gizi Geriatri. Muhammadiyah University Press.

Sitanggang, Y. dkk. 2021. Keperawatan Gerontik. Yayasan Kita Menulis.

Surbakti, S. (2014). Pengaruh latihan jalan kaki 30 menit terhadap penurunan tekanan darah pada pasien penderita hipertendi di rumah sakit umum Kabanjahe. Jurnal Pengabdian Kepada Masyarakat, 20(77).

Sunaryo, dkk. 2015. Asuhan Keperawatan Gerontik. PT CV ANDI. Yogyakarta. 